\section{Preplant Storage and Greenhouse Temperature Influence Flowering of Ornithogalum}

\author{
Judy Lee ${ }^{1}$ and William B. Miller ${ }^{2,3}$ \\ Horticulture Section, School of Integrative Plant Science, Cornell University, \\ 134 Plant Science Building, Ithaca, NY 14853
}

Additional index words. facultative vernalization, flower bulb, potted flower, Ornithogalum dubium, Ornithogalum thyrsoides, star of bethlehem

\begin{abstract}
We determined the effects of preplant storage temperature and duration and greenhouse growing temperature on the growth and flowering of four cultivars of potted Ornithogalum representing Ornithogalum dubium (three cultivars) and Ornithogalum thyrsoides (one cultivar) originating from Israeli breeding. Bulbs were stored at five temperatures for 1 to 4 weeks before planting. Within the range of 9 to $27^{\circ} \mathrm{C}$, lower preplant storage temperature resulted in earlier flowering and taller plants, and for one cultivar, increased bulb respiration measured after storage. When bulbs were stored at $9^{\circ} \mathrm{C}$ for 3 weeks, plants flowered at least 12 days earlier compared with controls stored at $27^{\circ} \mathrm{C}$. At $9{ }^{\circ} \mathrm{C}$, as preplant bulb storage duration increased from 0 to 4 weeks, plants flowered more quickly and were taller. Within the range of 13 to $21^{\circ} \mathrm{C}, 17$ to $18{ }^{\circ} \mathrm{C}$ forcing temperatures gave the best combination of forcing time and plant quality.
\end{abstract}

Ornithogalum sp. are ornamental geophytes in the Asparagaceae family. The inflorescence is a simple raceme consisting of several florets with six petals in two whorls (Huxley et al., 1992). Native to the Western Cape of South Africa, $O$. thyrsoides and $O$. dubium, commonly called star of bethlehem, were first introduced to the market as cut flowers. More recently, shorter-stemmed clones and cultivars of both species have been selected and are gaining popularity as potted flowering plants (Littlejohn and Blomerus, 1997, 2000; Luria et al., 2002; Reinten et al., 2011). In the U.S. market, potted geophytes used as winter-blooming house plants are especially in demand (Daly and Henry, 2009). To support the further commercialization of potted Ornithogalum, more information on preplant environmental conditions and greenhouse protocols is needed.

Determination of proper temperature sequences for the entirety of bulb production and utilization is an important aspect of flower bulb horticulture. In the Ornithogalum production cycle, the first stage of bulb storage is the period immediately after bulb harvest and before shipping. The effects of temperature after lifting have been studied for a number of Ornithogalum species. Warm $\left(25-30{ }^{\circ} \mathrm{C}\right)$ storage immediately after harvest promotes the ability of some species of Ornithogalum bulbs (Roh et al., 2007) to respond to later flower induction cues or bulb

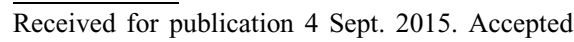
for publication 13 Nov. 2015.

We thank Yodfat Revivim Horticulture Ltd. and the Fred C. Gloeckner Company for donating bulbs.

${ }^{1}$ Graduate Student

${ }^{2}$ Professor

${ }^{3}$ Corresponding author. E-mail: wbm8@cornell.edu. vernalization treatments, resulting in higher percentages of flowering or earlier flowering (Jansen van Vuuren, 1997; Jansen van Vuuren and Holtzhausen, 1992; Roh and Hong, 2007; Roh and Joung, 2004; Roh and Suh, 2008).

The second stage of bulb storage is the preplant storage phase when bulbs are subjected to cool temperatures before planting. Previous research indicated that preplant cool storage of Ornithogalum bulbs accelerated flowering. Roh and Hong (2007) recommended holding $O$. thyrsoides bulbs at $10^{\circ} \mathrm{C}$ for 3 to 4 weeks or at $13{ }^{\circ} \mathrm{C}$ for 3 weeks to accelerate flowering and produce two or more inflorescences. Jansen van Vuuren and Holtzhausen (1992) reported that following 8 weeks of $25{ }^{\circ} \mathrm{C}$ storage after lifting, O. thyrsoides bulbs held at $5{ }^{\circ} \mathrm{C}$ for 6 weeks flowered earlier than bulbs held at $25^{\circ} \mathrm{C}$. With $O$. dubium, 3 weeks of dry storage at $13{ }^{\circ} \mathrm{C}$ resulted in significantly longer flower stems (taller plants) than treatments at 2,9 , and $25^{\circ} \mathrm{C}$ (Luria et al., 2002). The duration of preplant cooling at $13{ }^{\circ} \mathrm{C}$ did not affect the time from planting to flowering, which was $20 \pm$ 1 weeks. However, $13{ }^{\circ} \mathrm{C}$ for at least 2 weeks resulted in significantly longer flower stems compared with noncooled bulbs (Luria et al., 2002). De Hertogh and Gallitano (1997) reported that storing $O$. dubium bulbs at $9^{\circ} \mathrm{C}$ for 4 weeks resulted in taller plants and decreased the number of inflorescences and days to flower compared with bulbs treated with $17{ }^{\circ} \mathrm{C}$. They suggested that for potted plant production, bulbs should be stored at $17^{\circ} \mathrm{C}$ for 4 weeks before planting. Suh et al. (2000) found that time from planting to flowering of $O$. dubium was reduced by 9 to $30 \mathrm{~d}$ when bulbs were stored at 10,15 , or $20^{\circ} \mathrm{C}$ for 4 or 6 weeks compared with $25^{\circ} \mathrm{C}$ controls. Contrary to the above studies, however, the number of flowers was significantly reduced and the inflorescences were shorter when bulbs were stored for 6 weeks at 10,15 , or $20{ }^{\circ} \mathrm{C}$ compared with the $25^{\circ} \mathrm{C}$ control (Suh et al., 2000).

Cultural recommendations for Israeli-grown bulbs grown as container plants (Yodfat Revivim Horticulture, personal communication) suggest that holding bulbs for 3 weeks at $13{ }^{\circ} \mathrm{C}$ will speed flowering. However, we believe additional information will be helpful for growers to determine proper storage preplant temperature and duration for newly developed cultivars.

The floriculture industry must pay attention to the cost and profitability of production procedures (Miller, 2003). The average daily plant-growing temperature can be adjusted to speed up or slow down the development of a crop, but consideration must be given to whether the longer growing time at the cooler temperature greenhouse is actually more costly or not. With $O$. dubium, flowering was much faster under a $27 / 22{ }^{\circ} \mathrm{C}$ day/night temperature regime compared with $17 / 12{ }^{\circ} \mathrm{C}$ (Luria et al., 2002). Flowering of Ornithogalum arabicum and $O$. dubium was accelerated by 8 to $19 \mathrm{~d}$, respectively, when plants were forced at $19 / 13^{\circ} \mathrm{C}$ as compared with $13 / 10^{\circ} \mathrm{C}$ (Suh et al., 2000). Warmer temperatures had no effect (O. arabicum) or slightly lengthened (O. dubium) inflorescences (Suh et al., 2000). Conversely, plants were shorter when grown at warmer temperatures $(22 / 17,27 / 22$, and $32 / 27^{\circ} \mathrm{C}$ ) compared with $17 / 12{ }^{\circ} \mathrm{C}$ (Luria et al., 2002). Additional data on Ornithogalum response to growing temperature with named cultivars seems warranted.

The objective of this research was to expand the available information on preplant storage temperatures and durations and greenhouse forcing temperature on the growth and flowering of potted Ornithogalum.

\section{Materials and Methods}

General procedure. Four cultivars were used: $O$. dubium 'Fire Star', 'Yellow Star', and 'Orange Star 511' and $O$. thyrsoides 'White Star'. Bulbs (3-4 cm circumference) arrived from Israel on 9 Aug. 2013 and were kept ventilated at $27^{\circ} \mathrm{C}$ in darkness until use. Bulbs had been harvested in late June to early July in Israel and kept at $25{ }^{\circ} \mathrm{C}$ after lifting (David Effron, personal communication). On arrival, bulbs exhibited no visible external growth. Bulbs were cut and examined under a microscope after 3 weeks of $27^{\circ} \mathrm{C}$ storage in Ithaca, by which time they had been exposed to $25-27{ }^{\circ} \mathrm{C}$ for a total of 7 to 9 weeks after lifting. At that time, no flower primordia were observed in any cultivar.

Before giving treatments, bulbs were visually graded and inferior bulbs removed. There were six replicates (pots) for each treatment and cultivar. Three bulbs were planted per $12.7 \mathrm{~cm}$ round plastic azalea pot. The planting medium was a soilless peat-based substrate (LM-111; Lambert Peat Moss, Inc., Riviere-Ouelle, Quebec, Canada). Plants were grown in glass greenhouses 
with fan and pad cooling and computerized controls at a constant air temperature set point of $17{ }^{\circ} \mathrm{C}$ (unless otherwise specified). Temperatures were monitored at 15-min intervals by aspirated Hobo dataloggers (Onset Computer Corp., Bourne, MA). Plants were irrigated as needed with tap water. Fertilizer was provided by $150 \mathrm{mg} \cdot \mathrm{L}^{-1} \mathrm{~N}$ from Jack's Professional Water Soluble Fertilizer (21-520; J.R. Peter's Inc., Allentown, PA) every 10 days, with $674 \mathrm{mg} \cdot \mathrm{L}^{-1} \mathrm{MgSO}_{4}$ added. Data were collected on the date the date of visible bud (VB, defined as the time when one plant in the pot had a bud height of $1.5 \mathrm{~cm}$ and width of $0.5 \mathrm{~cm}$ ) and the date of first flowering (when the first one or two florets of the first plant to flower per pot were open). On the day of first flower opening, leaf length, number of leaves, inflorescence length (portion of the stem with florets attached), scape length (leafless stem below the lowest attached floret to the soil surface), and plant height (the sum of inflorescence length and scape length) were recorded on the flowering plant. Unless indicated, all experiments were of a completely randomized design. Data were analyzed using JMP (SAS, Inc. Cary, NC).

Expt. 1: Bulb preplant storage temperatures. On 6 Sept. and 20 Sept., bulbs were stored (preplant storage) for 3 weeks at 9, 13, 16, 20 , or $27{ }^{\circ} \mathrm{C}$ (designated as the control). Bulbs were planted on 27 Sept. or 11 Oct. 2013, respectively. A "no storage" treatment was planted and placed in the greenhouse when the other bulbs were put into the preplant storage treatments.

After storage and before planting, bulb respiration was measured by headspace accumulation of $\mathrm{CO}_{2}$. There were six replicates, each with three bulbs per treatment temperature. Bulbs were placed into $125-\mathrm{mL}$ jars that were flushed $30 \mathrm{~s}$ with pressurized fresh air and sealed with lids containing a septum. After incubation for 5 or $6 \mathrm{~h}$ at $22{ }^{\circ} \mathrm{C}, 1 \mathrm{~mL}$ head space air was taken from each jar and $\mathrm{CO}_{2}$ concentration was determined with a CA-10a $\mathrm{CO}_{2}$ analyzer (Sable Systems Intl., Las Vegas, NV) in a "gas chromatograph" mode using $\mathrm{N}_{2}\left(800 \mathrm{~mL} \cdot \mathrm{min}^{-1}\right)$ as a carrier gas. Calibration was by known $\mathrm{CO}_{2}$ standards in nitrogen.

Expt. 2: Duration of preplant $9{ }^{\circ} \mathrm{C}$ cooling. Bulbs were stored at $9{ }^{\circ} \mathrm{C}$ for 0,1 , 2,3 , or 4 weeks before planting. As above, bulbs were kept at $27^{\circ} \mathrm{C}$ until each individual $9{ }^{\circ} \mathrm{C}$ treatment began (storage dates were staggered so all ended simultaneously).
Bulbs were planted after storage treatments ended (Oct. 6), and an identical, repeat experiment was planted on 20 Oct. 2013. After storage and before planting, bulb respiration was measured as above with three replicate jars per treatment and six bulbs per replicate.

Expt. 3: Greenhouse forcing temperature. General procedures were as above except as follows. Three cultivars were used: Ornithogalum dubium 'Fire Star' and 'Yellow Star', and $O$. thyrsoides 'White Star'. Bulbs arrived from Israel on 17 Sept. 2012. There were eight replicates (pots) with three bulbs per pot for each treatment and cultivar. Bulbs were held at $16{ }^{\circ} \mathrm{C}$ for 3 weeks immediately before planting as this treatment is generally thought to be beneficial for flowering (Yodfat Revivim Horticulture, personal communication). The experiment was conducted twice (planting dates of 17 and 31 Oct. 2012) and grown in greenhouses with air temperature set points of $13,17,18$, or $21^{\circ} \mathrm{C}$.

\section{Results}

Expt. 1: Bulb preplant storage temperatures. Data from the $13{ }^{\circ} \mathrm{C}$ treatment in the first planting date are not included in the analysis because of fluctuating temperatures due to equipment failure.

Leaf length was affected by cultivar and plant date but preplant storage temperature had no effect (Table 1). Overall, leaves were slightly longer in the early planted group (Table 2). 'White Star' had the longest leaves and 'Fire Star' had the shortest. The number of leaves per plant was highly affected by cultivar and preplant storage temperature with a weak interaction of cultivar and planting date. In general, 'Yellow Star' had the fewest leaves and 'White Star' had the most.

The cultivar $\times$ planting date interaction was significant for days from planting to flower; time to flower was less for later planting dates. 'Orange Star' was the slowest cultivar to flower and 'Yellow Star' was the fastest (Table 2). All four cultivars had a linear response to storage temperature and the lowest storage temperature tested, $9{ }^{\circ} \mathrm{C}$, caused the fastest flowering. Compared with $27{ }^{\circ} \mathrm{C}$ plants, preplant $9{ }^{\circ} \mathrm{C}$ storage caused plants to flower 22, 18, 12, and 15 (first planting date) and 8,11, 16, and 9 (second planting dater) days earlier in 'Fire Star', 'Orange Star 511', 'White Star', and 'Yellow Star', respectively (Table 2). While cooler storage temperatures reduced time to flower, the effect was more pronounced in the early planted group.

For 'Fire Star' and 'Yellow Star', the faster flowering resulting from $9{ }^{\circ} \mathrm{C}$ storage was almost entirely due to shortening the duration from VB to flower since the time from planting to VB was not greatly affected (Table 2). Such a clear relationship was not seen for 'White Star' and 'Orange Star 511' (Table 2). For this parameter, the cultivar and temperature and temperature and plant date interactions were significant. However, there was a clear trend toward reduced time from $\mathrm{VB}$ to flower as the preplant storage temperature decreased from 29 to $9{ }^{\circ} \mathrm{C}$. For 'Fire Star', $9{ }^{\circ} \mathrm{C}$ preplant storage reduced time from VB to flower by nearly 3 weeks for both planting dates compared with $27^{\circ} \mathrm{C}$ (Table 2 ) whereas less pronounced differences were seen with 'Orange Star 511'.

All interactions for time from planting to VB were nonsignificant but the three main effects of cultivar, storage temperature and planting date were highly significant (Table 1). 'Yellow Star' reached VB the fastest, followed by 'Fire Star', then 'White Star' and 'Orange Star 511'. Lower storage temperature reduced the days to VB in 'Orange Star' (first planting only) had a quadratic effect in 'White Star' for both plant dates and in 'Yellow Star' for the last plant date, only (Table 2). Although significant, these changes were less horticulturally important than the changes in date from VB to flower.

The "no storage" treatment, which was planted in the greenhouse on the date the other storage treatments began, flowered in the greenhouse on very nearly the same date as the $9{ }^{\circ} \mathrm{C}$ treatment in 'Fire Star' and 'Orange Star 511'. However, these plants required 21 more days in the greenhouse to do so as these plants were placed in the greenhouse on the date storage began for the other bulbs. For 'White Star', the average increase in forcing time for the nonstored plants was $32 \mathrm{~d}$, greater than the length of the storage period, indicating the $9^{\circ} \mathrm{C}$ preplant storage treatment accelerated flowering even accounting for the 3-week storage period. In 'Yellow Star', while $9{ }^{\circ} \mathrm{C}$ treatments required fewer days in the greenhouse, when the 3 weeks of storage is added, flowering in the greenhouse was actually later than nonstored controls (Table 2).

The three-way interaction for plant height and scape length was significant for plant height and scape length. Both increased as

Table 1. Analysis of variance of Ornithogalum plant characteristics as influenced by cultivar, preplant storage temperature, and planting date. Expt. 1.

\begin{tabular}{|c|c|c|c|c|c|c|c|c|}
\hline & $\begin{array}{c}\text { Leaf } \\
\text { length }(\mathrm{cm})\end{array}$ & No. of leaves & $\begin{array}{c}\text { Days from } \\
\text { planting to } \mathrm{VB}\end{array}$ & $\begin{array}{c}\text { Days from } \\
\text { planting to flower }\end{array}$ & $\begin{array}{c}\text { Days from } \\
\text { VB to flower }\end{array}$ & Plant ht $(\mathrm{cm})$ & $\begin{array}{c}\text { Scape } \\
\text { length }(\mathrm{cm})\end{array}$ & $\begin{array}{l}\text { Inflorescence } \\
\text { length }(\mathrm{cm})\end{array}$ \\
\hline Cultivar (C) & $* * *$ & $* * *$ & $* * *$ & $* * *$ & $* * *$ & $* * *$ & $* * *$ & $* * *$ \\
\hline Storage temp $(\mathrm{T})$ & NS & $* * *$ & $* *$ & $* * *$ & $* * *$ & $* * *$ & $* * *$ & NS \\
\hline Plant date $(\mathrm{P})$ & $* * *$ & NS & $* *$ & $* * *$ & $* * *$ & $* * *$ & $* * *$ & $* * *$ \\
\hline $\mathrm{C} \times \mathrm{T}$ & NS & NS & NS & NS & $* * *$ & $* * *$ & $* * *$ & $* * *$ \\
\hline $\mathrm{C} \times \mathrm{P}$ & NS & $*$ & NS & $* *$ & $* *$ & NS & NS & NS \\
\hline $\mathrm{T} \times \mathrm{P}$ & NS & NS & NS & NS & NS & NS & NS & NS \\
\hline $\mathrm{C} \times \mathrm{T} \times \mathrm{P}$ & NS & NS & NS & NS & NS & $*$ & $* *$ & NS \\
\hline
\end{tabular}

$\mathrm{NS}, *, * *, * * *$ Nonsignificant or significant at $P \leq 0.05,0.01$, or 0.001 , respectively. 
Table 2. Effect of prestorage temperature and planting date on plant characteristics of four cultivars of Ornithogalum. Expt. 1.

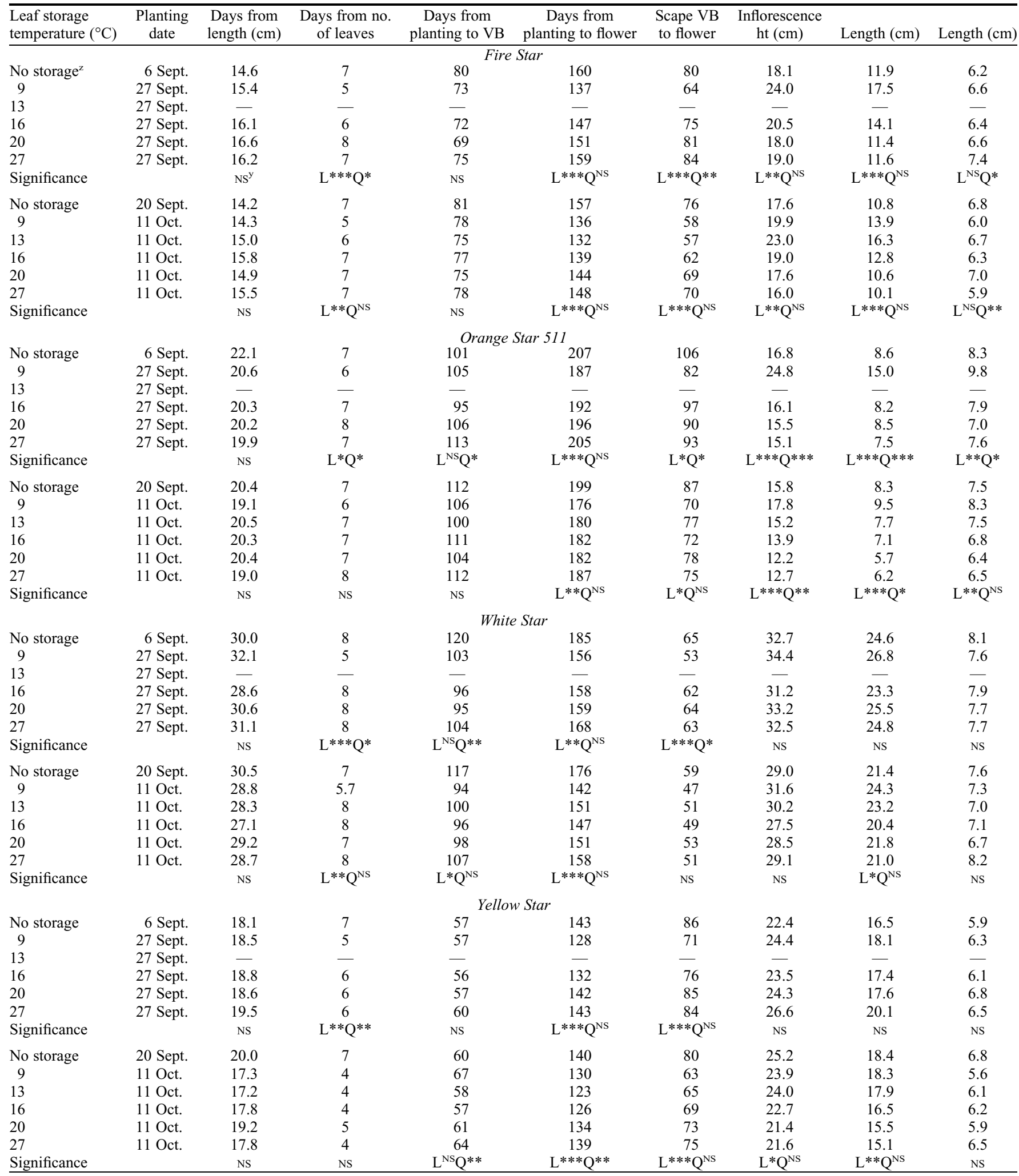

${ }^{\mathrm{z}}$ The no storage treatment was excluded from the regression analysis.

${ }^{\mathrm{y}}$ Significance of linear (L) or quadratic (Q) regression: NS, ${ }^{*}, * *, * *$ Nonsignificant or significant at $P \leq 0.05,0.01$, or 0.001 , respectively (for bulbs stored at 9 to $27^{\circ} \mathrm{C}$ only).

preplant storage temperature decreased in 'Fire Star' and 'Orange Star 511', but there was no effect in 'White Star'. In 'Yellow Star', plant height and scape length responded differently according to planting date. Although the inflorescence length varied by treatment in some cultivars, the visual effect was not significant. There was no significant difference in leaf length among temperature treatments of any cultivar. For all cultivars, plants stored at $9{ }^{\circ} \mathrm{C}$ had the fewest leaves (Table 2).
The poststorage respiration rate (measured at $22{ }^{\circ} \mathrm{C}$ ) of Ornithogalum bulbs was affected by cultivar and storage temperature. When measured after 3 weeks of storage, 'White Star' showed a significant increase in respiration as prior storage temperature 
decreased from 27 to $9{ }^{\circ} \mathrm{C}$ (Fig. 1). Respiration of the other three cultivars was not significantly affected by temperature (Fig. 1).

Expt. 2: Duration of preplant $9{ }^{\circ} \mathrm{C}$ cooling. The full factorial analysis of variance showed there was a three-way interaction of cultivar, duration, and planting date on days from planting to VB and flower (Table 3 ), indicating that the cultivars responded differently to combinations of cooling duration and planting date.

For all cultivars and planting dates, increasing the duration of $9{ }^{\circ} \mathrm{C}$ preplant storage accelerated flowering. When bulbs were cooled at $9{ }^{\circ} \mathrm{C}$ for 4 weeks, flowering was accelerated by at least 25, 26, 20, and $18 \mathrm{~d}$ in 'Yellow Star', 'Fire Star', 'White Star', and 'Orange Star 511', respectively, compared with nonstored controls (Table 4). Increasing duration of preplant storage at $9{ }^{\circ} \mathrm{C}$ accelerated flowering more for the first planting date than the second. Plant height and scape length increased linearly with increasing storage time in all cultivars except 'Yellow Star'. Storage duration did not have an effect on inflorescence length except for 'Orange Star 511' in which increased duration resulted in a longer inflorescence (Table 4). All cultivars showed a decrease in the number of leaves with increased cooling duration (Table 4). Bulb respiration measurements after cooling showed a significant increase with increasing cooling duration in 'White Star' but there was no change in the other cultivars (Fig. 2).

Expt. 3: Greenhouse forcing temperature. For both planting dates, the actual 24-h average daily average temperatures for the

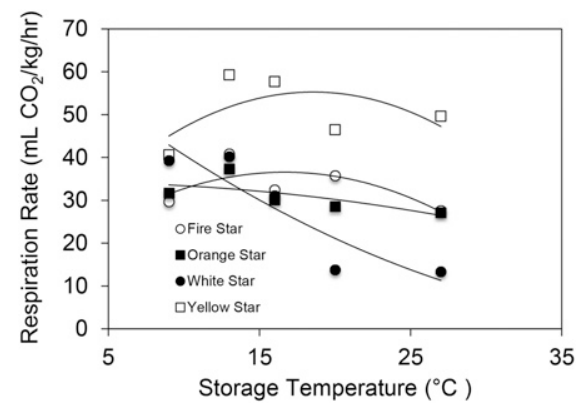

Fig. 1. Effect of 3 weeks preplant storage temperature regimes on bulb respiration rate (measured at $22^{\circ} \mathrm{C}$ ) for four Ornithogalum cultivars. The response to temperature was significant for 'White Star' (Prob > F $=0.0002 ; \mathrm{y}=0.032 \mathrm{x}^{2}$ $2.92 x+66.6)$. Response was nonsignificant for the other three cultivars. Expt. 1.
$13,17,18$, and $21^{\circ} \mathrm{C}$ greenhouses were 12.8 , $17.2,18.3$, and $21.3^{\circ} \mathrm{C}$, respectively.

Because the cultivars in this experiment represent at least two species and unknown genetic backgrounds, each is considered individually in the analysis below. Cultivars differed in time to flower. 'Yellow Star' was the fastest flowering cultivar, followed by 'Fire Star' and 'White Star', similar to results in Expt. 1 (Table 2). Growing at $21^{\circ} \mathrm{C}$ vs. $13{ }^{\circ} \mathrm{C}$ accelerated flowering by $\approx 75,60$, and $80 \mathrm{~d}$ for 'Fire Star', 'White Star', and 'Yellow Star', respectively. Warm temperatures reduced the days required to reach $\mathrm{VB}$, but an even larger effect was seen in the period from VB to flowering (Table 5).

Warmer forcing temperature decreased inflorescence length in 'Yellow Star' and 'Fire Star' and there was a quadratic relationship between plant height and greenhouse temperature. The shortest plants occurred either in the $17{ }^{\circ} \mathrm{C}$ or the $18{ }^{\circ} \mathrm{C}$ treatments in 'Yellow Star' and 'Fire Star' in both planting dates. Greenhouse temperature did not consistently affect plant height in 'White Star' (Table 5).

Warmer forcing temperatures increased leaf length. The effect was consistent for all cultivars and between the two planting dates (Table 5). Warmer forcing temperatures slightly increased the number of leaves in 'Fire Star' and 'Yellow Star'.

Although the highest forcing temperature $\left(21^{\circ} \mathrm{C}\right)$ resulted in earliest flowering, visual plant quality was reduced due to lighter green leaves and less compact plants. While plants grown at $13{ }^{\circ} \mathrm{C}$ were of excellent quality, plants flowered significantly later than other temperature treatments in all three cultivars.

\section{Discussion}

As a new crop, and especially in the context of container plant production, Ornithogalum suffers from a relative lack of published research, much of which has used nonclonal material (Jansen van Vuuren, 1997; Luria et al., 2002; Suh et al., 2000), or was done with cultivars that are no longer available or unidentifiable (De Hertogh and Gallitano, 1997). Still other work was published on a cultivar more suited for cut flower production (Roh and Hong, 2007; Roh et al., 2007). Thus, relating the present studies into an existing framework is difficult.

Short, compact plants are optimal for potted plant production. Luria et al. (2002) found the longest flower stems (tallest plants) occurred from bulbs stored at $13{ }^{\circ} \mathrm{C}$ vs. 2,9 , or $25^{\circ} \mathrm{C}$, but others (De Hertogh and Gallitano, 1997) found that the tallest plants came from bulbs stored at $9{ }^{\circ} \mathrm{C}$. Consistent with this work, our experiments showed that three of the four cultivars were taller as a result of lower preplant storage temperatures. Thus, considering only plant height and the desire to keep plants short and compact, a warmer preplant storage temperature $\left(27^{\circ} \mathrm{C}\right)$ is optimum as it yields shorter final plants.

With regards to time to flower, however, Suh et al. (2000) found that storing O. dubium bulbs at 10,15 , or $20^{\circ} \mathrm{C}$ for 4 or 6 weeks reduced the time from planting to flowering compared with control bulbs stored at warmer temperatures $\left(25^{\circ} \mathrm{C}\right)$. Similarly, we found that with 3-week preplant storage, the time from planting to flowering exhibited a linear reduction as storage temperature decreased from 27 to $9{ }^{\circ} \mathrm{C}$. This was seen with all cultivars and was consistent between 2 years of experiments. Similar results were seen by De Hertogh and Gallitano (1997) where 4 weeks storage at $9{ }^{\circ} \mathrm{C}$ resulted in taller plants and decreased days to flower compared with those stored at $17{ }^{\circ} \mathrm{C}$. Thus, all evidence suggests that 3 weeks of storage at temperatures below $27{ }^{\circ} \mathrm{C}$ will accelerate flowering of $O$. dubium. While this is a positive effect, our work clearly shows that cool storage also causes taller plants (see above), an undesirable effect. Thus, for potted plants, appropriate use of an antigibberellin growth regulator will likely be needed to control taller (undesirable) plants that occur with lower temperature storage needed for faster flowering. Our previous work (Lee et al., 2015) will be helpful in this regard.

Respiration data showed that bulb metabolic activity increased in 'White Star' after cooling treatments (Figs. 1 and 2). The preplant cool temperature may have stimulated early events in flower induction, resulting in increased respiration rate; however, the absolute significance of the respiration change is unknown.

In all cultivars tested, the time from planting to flowering exhibited a linear reduction with decreased preplant storage temperature from 27 to $9{ }^{\circ} \mathrm{C}$. Vernalization induces or hastens the development of the capacity for flowering of vegetative meristems and appears as an aftereffect of the low temperature (Chouard, 1960), which is only seen after plants are returned to a warmer, conducive growth environment. We dissected bulbs and confirmed they were

Table 3. Analysis of variance of Ornithogalum plant characteristics as influenced by cultivar, cooling duration, and planting date. Expt. 2.

\begin{tabular}{|c|c|c|c|c|c|c|c|c|}
\hline & Leaf length $(\mathrm{cm})$ & No. of leaves & $\begin{array}{c}\text { Days from } \\
\text { planting to VB }\end{array}$ & $\begin{array}{l}\text { Days from } \\
\text { planting to flower }\end{array}$ & $\begin{array}{l}\text { Days from } \\
\text { VB to flower }\end{array}$ & Plant ht $(\mathrm{cm})$ & Scape length $(\mathrm{cm})$ & $\begin{array}{l}\text { Inflorescence } \\
\text { length }(\mathrm{cm})\end{array}$ \\
\hline Cooling duration (D) & NS & $* * *$ & $* * *$ & $* * *$ & $* * *$ & $* * *$ & $* * *$ & NS \\
\hline Planting date $(\mathrm{P})$ & $* * *$ & NS & $*$ & $* * *$ & $* * *$ & $*$ & $* * *$ & NS \\
\hline $\mathrm{C} \times \mathrm{P}$ & $* * *$ & $*$ & $* * *$ & NS & $* *$ & $* * *$ & $* * *$ & $*$ \\
\hline $\mathrm{D} \times \mathrm{P}$ & NS & NS & NS & $* * *$ & $* * *$ & NS & NS & NS \\
\hline $\mathrm{C} \times \mathrm{D} \times \mathrm{P}$ & NS & NS & ** & $*$ & NS & NS & NS & NS \\
\hline
\end{tabular}

Ns, $* * *, * * *$ Nonsignificant or significant at $P \leq 0.05,0.01$, or 0.001 , respectively. 
Table 4. Effect of cooling duration and planting date on plant characteristics of four cultivars of Ornithogalum. Expt. 2.

\begin{tabular}{|c|c|c|c|c|c|c|c|c|c|}
\hline $\begin{array}{l}\text { Leaf storage } \\
\text { temp. }\left({ }^{\circ} \mathrm{C}\right)\end{array}$ & Planting date & $\begin{array}{c}\text { Days } \\
\text { from length }(\mathrm{cm})\end{array}$ & $\begin{array}{c}\text { Days from no. } \\
\text { of leaves }\end{array}$ & $\begin{array}{c}\text { Days from } \\
\text { planting to VB }\end{array}$ & $\begin{array}{l}\text { Plant planting } \\
\text { to flower }\end{array}$ & $\begin{array}{l}\text { Scape VB } \\
\text { to flower }\end{array}$ & $\begin{array}{l}\text { Inflorescence } \\
\text { ht }(\mathrm{cm})\end{array}$ & Length $(\mathrm{cm})$ & Length $(\mathrm{cm})$ \\
\hline $\begin{array}{l}0 \\
1 \\
2 \\
3 \\
4 \\
\text { Significance }\end{array}$ & 6 Oct. & $\begin{array}{c}19.8 \\
18.9 \\
20.2 \\
20.6 \\
21.2 \\
\text { NS }\end{array}$ & $\begin{array}{c}7 \\
7 \\
7 \\
6 \\
5 \\
\mathrm{~L}^{*} \mathrm{Q}^{\mathrm{NS}}\end{array}$ & $\begin{array}{c}\text { Orange Star } \\
111 \\
112 \\
105 \\
97 \\
94 \\
\mathrm{~L}^{* * *} \mathrm{Q}^{\mathrm{NS}}\end{array}$ & $\begin{array}{c}197 \\
195 \\
188 \\
175 \\
163 \\
\mathrm{~L}^{* * *} \mathrm{Q}^{*}\end{array}$ & $\begin{array}{c}86 \\
83 \\
83 \\
78 \\
69 \\
\mathrm{~L}^{* * *} \mathrm{Q}^{\mathrm{NS}}\end{array}$ & $\begin{array}{c}14.1 \\
16.4 \\
18.1 \\
21.8 \\
22.9 \\
\mathrm{~L}^{* * *} \mathrm{Q}^{\mathrm{NS}}\end{array}$ & $\begin{array}{c}7.4 \\
8.3 \\
10.0 \\
13.0 \\
14.1 \\
\mathrm{~L}^{* * *} \mathrm{Q}^{\mathrm{NS}}\end{array}$ & $\begin{array}{c}6.7 \\
8.2 \\
8.1 \\
8.9 \\
8.8 \\
\mathrm{~L}^{*} \mathrm{Q}^{\mathrm{NS}}\end{array}$ \\
\hline $\begin{array}{l}0 \\
1 \\
2 \\
3 \\
4 \\
\text { Significance }\end{array}$ & 20 Oct. & $\begin{array}{c}19.8 \\
17.2 \\
17.6 \\
19.8 \\
19.2 \\
\text { NS }\end{array}$ & $\begin{array}{c}7 \\
7 \\
6 \\
6 \\
5 \\
\mathrm{~L}^{* * *} \mathrm{Q}^{\mathrm{NS}}\end{array}$ & $\begin{array}{c}107 \\
108 \\
111 \\
101 \\
94 \\
\mathrm{~L}^{* * *} \mathrm{Q} * *\end{array}$ & $\begin{array}{c}184 \\
175 \\
184 \\
176 \\
165 \\
\mathrm{~L}^{*} \mathrm{Q}^{\mathrm{NS}}\end{array}$ & $\begin{array}{l}77 \\
68 \\
73 \\
75 \\
71 \\
\text { NS }\end{array}$ & $\begin{array}{c}14.5 \\
14.3 \\
17.7 \\
19.1 \\
22.4 \\
\mathrm{~L}^{* * *} \mathrm{Q}^{\mathrm{NS}}\end{array}$ & $\begin{array}{c}7.4 \\
7.9 \\
9.9 \\
10.0 \\
13.1 \\
\mathrm{~L}^{* * *} \mathrm{Q}^{\mathrm{NS}}\end{array}$ & $\begin{array}{c}7.2 \\
6.4 \\
7.8 \\
9.1 \\
9.3 \\
\mathrm{~L}^{* * *} \mathrm{Q}^{\mathrm{NS}}\end{array}$ \\
\hline $\begin{array}{l}0 \\
1 \\
2 \\
3 \\
4 \\
\text { Significance }\end{array}$ & 6 Oct. & $\begin{array}{c}27.8 \\
26.8 \\
30.1 \\
28.9 \\
30.4 \\
\text { NS }\end{array}$ & $\begin{array}{c}8 \\
8 \\
8 \\
7 \\
6 \\
\mathrm{~L}^{* *} \mathrm{Q}^{\mathrm{NS}}\end{array}$ & $\begin{array}{l}\text { White Sta } \\
111 \\
103 \\
101 \\
94 \\
90 \\
\mathrm{~L}^{* * *} \mathrm{Q}^{\mathrm{NS}}\end{array}$ & $\begin{array}{c}171 \\
162 \\
160 \\
152 \\
139 \\
\mathrm{~L}^{* * *} \mathrm{Q}^{*}\end{array}$ & $\begin{array}{c}60 \\
59 \\
59 \\
58 \\
48 \\
\mathrm{~L}^{* *} \mathrm{Q}^{*}\end{array}$ & $\begin{array}{c}31.8 \\
31.9 \\
36.4 \\
33.9 \\
35.8 \\
\mathrm{~L}^{*} \mathrm{Q}^{\mathrm{NS}}\end{array}$ & $\begin{array}{c}24.0 \\
24.0 \\
28.4 \\
26.6 \\
28.1 \\
\mathrm{~L}^{* *} \mathrm{Q}^{\mathrm{NS}}\end{array}$ & $\begin{array}{l}7.8 \\
7.9 \\
8.0 \\
7.2 \\
7.7 \\
\text { NS }\end{array}$ \\
\hline $\begin{array}{l}0 \\
1 \\
2 \\
3 \\
4 \\
\text { Significance }\end{array}$ & 20 Oct. & $\begin{array}{c}18.6 \\
18.5 \\
18.6 \\
18.3 \\
16.8 \\
\mathrm{~L}^{*} \mathrm{Q}^{\mathrm{NS}}\end{array}$ & $\begin{array}{c}5 \\
5 \\
4 \\
5 \\
4 \\
\mathrm{~L}^{*} \mathrm{Q}^{\mathrm{NS}}\end{array}$ & $\begin{array}{c}70 \\
65 \\
70 \\
58 \\
50 \\
\mathrm{~L}^{* * *} \mathrm{Q}^{* *}\end{array}$ & $\begin{array}{c}140 \\
139 \\
134 \\
123 \\
115 \\
\mathrm{~L}^{* * *} \mathrm{Q} * * *\end{array}$ & $\begin{array}{c}70 \\
74 \\
64 \\
66 \\
65 \\
\mathrm{~L}^{* *} \mathrm{Q}^{\mathrm{NS}}\end{array}$ & $\begin{array}{c}26.0 \\
26.6 \\
27.0 \\
27.4 \\
26.3 \\
\text { NS }\end{array}$ & $\begin{array}{c}19.5 \\
19.4 \\
20.7 \\
20.7 \\
20.3 \\
\text { NS }\end{array}$ & $\begin{array}{l}6.5 \\
7.2 \\
6.2 \\
6.7 \\
6.0 \\
\text { NS }\end{array}$ \\
\hline
\end{tabular}

Leaf length, number of leaves, plant height, scape length, and inflorescence length data were collected when first one or two florets flowered.

${ }^{z}$ Significance of linear $(\mathrm{L})$ or quadratic $(\mathrm{Q})$ regression: NS, ${ }^{*}, * *, * * *$ Nonsignificant or significant at $P \leq 0.05,0.01$, or 0.001 , respectively.

vegetative at the start of temperature treatments. Since the controls (stored at $27^{\circ} \mathrm{C}$ ) flowered without cool temperature treatment, the promotive effect of cool preplant storage temperature on Ornithogalum bulbs appears to be an example of facultative or quantitative vernalization, that is, cold promoted flowering but was not strictly required. To sum up, bulbs probably reached a "mature state" during the warm storage period in Israel (Jansen van Vuuren, 1997; Roh and Joung, 2004). When bulb "maturity" was reached, they had the capacity to perceive a vernalization treatment. Preplant storage at $\operatorname{cool}\left(9{ }^{\circ} \mathrm{C}\right.$ and somewhat above) temperature induced flower initiation and hastened the rate of differentiation and flowering after planting in greenhouse, which is the aftereffect of vernalization.

Although, depending on the cultivar, plants with a 3-week precooling treatment did not necessarily flower ahead of the plants planted earlier without any cooling (Table 2), the precooling treatment did reduce the time plants required in the greenhouse. Because greenhouse operation is expensive, fewer days in the greenhouse would reduce overall production cost. Also, in 'Fire Star', 'White
Star', and 'Yellow Star', there was a higher standard deviation observed in the days from planting to flower in the "no storage" treatment compared with those stored at cooler temperatures (data not shown). Therefore, preplant cooling treatment also had a positive effect on achieving a more uniform crop.

Previous work investigating the duration of $13{ }^{\circ} \mathrm{C}$ precooling found that at least 2 weeks of $13{ }^{\circ} \mathrm{C}$ treatment resulted in significantly taller plants, but had no effect on flowering time (Luria et al., 2002). In our work, three of the four cultivars were taller and had longer scapes with increasing storage 
duration at $9{ }^{\circ} \mathrm{C}$. The fourth, 'Yellow Star', was unaffected. Contrary to Luria et al. (2002), however, in all cultivars we saw faster flowering and reduced time from planting to $\mathrm{VB}$ and from VB to flower as cooling duration increased.

We did observe that preplant cooling suppressed the second rosette of leaf growth

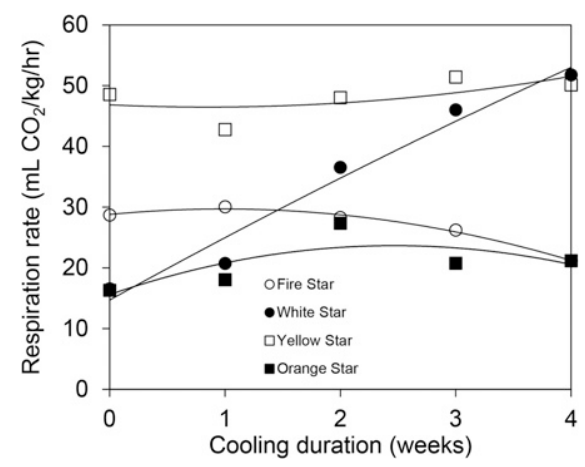

Fig. 2. Effect of preplant $9{ }^{\circ} \mathrm{C}$ duration on bulb respiration rate for four Ornithogalum cultivars measured at $22{ }^{\circ} \mathrm{C}$. The response to storage duration was significant for 'White Star' (Prob > $\left.\mathrm{F}=0.0001 ; \mathrm{y}=-0.23 \mathrm{x}^{2}+9.58 \mathrm{x}+15.64\right)$. Response was nonsignificant for the other three cultivars. Expt. 2. and its associated inflorescence development. Although we did not collect data, most of the $O$. dubium plants that were cooled for 3 or 4 weeks at $9{ }^{\circ} \mathrm{C}$ had only one inflorescence while those with less cooling often had two. Similar observations of cool storage suppressing second inflorescence development were seen with $O$. thyrsoides (Roh and Hong, 2007).

As in prior work, O. dubium plants flowered earlier when grown at warmer temperatures. Luria et al. (2002) found that flowering was $\approx 40$-d faster under a $27 / 22{ }^{\circ} \mathrm{C}$ day/night temperature regime compared with a $17 / 12{ }^{\circ} \mathrm{C}$ regime. Suh et al. (2000) found that flowering of $O$. dubium was accelerated by $19 \mathrm{~d}$ when plants were grown at $19 / 13{ }^{\circ} \mathrm{C}$ compared with $13 / 10{ }^{\circ} \mathrm{C}$. However, in our experiment, plants grown at $17^{\circ} \mathrm{C}$ flowered much faster than in the Suh et al. (2000) report, some 30 to $50 \mathrm{~d}$ earlier, than plants grown at $13{ }^{\circ} \mathrm{C}$. The magnitude of difference in flowering time may be due to different species and cultivars being used. There was a positive DIF (difference in day temperature minus night temperature; Erwin et al., 1989) in the previous work, while in our experiments, all greenhouse temperatures were constant. DIF might contribute to the magnitude of difference in flowering time, but more work will be needed to determine this. Also, the actual average growing temperatures were not provided in the previous work, so it's difficult to make accurate comparisons.

The effect of growing temperature on inflorescence length remains unclear. Suh et al. (2000) found longer inflorescences when plants were forced at warmer temperatures. Conversely, our results and those of Luria et al. (2002) show longer inflorescences and taller plants when grown cooler (Table 5). But our results also showed a quadratic relationship between plant height and temperature, with shortest plants at $17^{\circ} \mathrm{C}$ or $19^{\circ} \mathrm{C}$. The seeming inconsistencies among Ornithogalum research results is likely due to differences in cultivar, growing environment (light and temperature), source and prior handling of the planting material, and a number of other factors. Additional research, over time, will clarify trends and allow more defined protocols for producing and managing this new crop.

Taking into consideration forcing time, plant height and visual quality, we conclude that 17 to $19{ }^{\circ} \mathrm{C}$ (constant) are the most suitable forcing temperatures for production of potted Ornithogalum, similar to the $18{ }^{\circ} \mathrm{C}$ night $/ 22{ }^{\circ} \mathrm{C}$ day temperature recommended by De Hertogh and Gallitano (1997). Although lower forcing temperatures will

Table 5. Effect of greenhouse temperature and planting date on plant characteristics of three cultivars of Ornithogalum. Expt. 3.

\begin{tabular}{|c|c|c|c|c|c|c|c|c|c|}
\hline $\begin{array}{l}\text { Leaf greenhouse } \\
\text { temp. }\left({ }^{\circ} \mathrm{C}\right)\end{array}$ & Planting date & $\begin{array}{l}\text { Days from } \\
\text { length }(\mathrm{cm})\end{array}$ & $\begin{array}{c}\text { Days from no. } \\
\text { of leaves }\end{array}$ & $\begin{array}{c}\text { Days from } \\
\text { planting to } \mathrm{VB}\end{array}$ & $\begin{array}{c}\text { Plant planting } \\
\text { to flower }\end{array}$ & $\begin{array}{l}\text { Scape VB } \\
\text { to flower }\end{array}$ & $\begin{array}{l}\text { Inflorescence } \\
\text { ht }(\mathrm{cm})\end{array}$ & Length (cm) & Length $(\mathrm{cm})$ \\
\hline \multicolumn{10}{|c|}{ Fire Star } \\
\hline 13 & 17 Oct. & 13.0 & 6 & 78 & 178 & 101 & 23.8 & 16.8 & 7.0 \\
\hline 17 & & 15.4 & 7 & 70 & 132 & 62 & 19.2 & 13.0 & 6.3 \\
\hline 18 & & 18.5 & 7 & 72 & 119 & 47 & 18.4 & 13.4 & 5.0 \\
\hline 21 & & 20.7 & 8 & 68 & 100 & 32 & 20.5 & 15.7 & 4.8 \\
\hline Significance & & $\mathrm{L}^{* * *} \mathrm{Q}^{\mathrm{NSz}}$ & $\mathrm{L}^{* *} \mathrm{Q}^{\mathrm{NS}}$ & $\mathrm{L}^{* * *} \mathrm{Q}^{\mathrm{NS}}$ & $\mathrm{L}^{* * *} \mathrm{Q} \mathrm{Q}^{* * *}$ & $\mathrm{~L}^{* * *} \mathrm{Q} \mathrm{Q}^{* * *}$ & $\mathrm{~L}^{* *} \mathrm{Q} * * *$ & $\mathrm{~L}^{\mathrm{NS}} \mathrm{Q}^{* * *}$ & $\mathrm{~L}^{* * *} \mathrm{Q}^{\mathrm{NS}}$ \\
\hline 13 & 31 Oct. & 12.1 & 6 & 81 & 176 & 95 & 22.8 & 16.2 & 6.6 \\
\hline 17 & & 15.3 & 8 & 69 & 133 & 64 & 19.3 & 12.8 & 6.6 \\
\hline 18 & & 17.2 & 7 & 59 & 117 & 57 & 19.0 & 13.1 & 5.9 \\
\hline 21 & & 21.8 & 7 & 58 & 101 & 43 & 19.8 & 15.0 & 4.9 \\
\hline Significance & & $\mathrm{L}^{* * *} \mathrm{Q} *$ & $\mathrm{~L}^{*} \mathrm{Q}^{*}$ & $\mathrm{~L}^{* * *} \mathrm{Q}^{*}$ & $\mathrm{~L} * * * \mathrm{Q}^{* * *}$ & $\mathrm{~L}^{* * *} \mathrm{Q} * *$ & $\mathrm{~L}^{* *} \mathrm{Q} * * *$ & $\mathrm{~L}^{\mathrm{NS}} \mathrm{Q}^{* * *}$ & $\mathrm{~L}^{* * *} \mathrm{Q} * *$ \\
\hline \multicolumn{10}{|c|}{ White Star } \\
\hline 13 & 17 Oct. & 24.1 & 8 & 99 & 180 & 81 & 25.8 & 20.0 & 5.7 \\
\hline 17 & & 23.4 & 8 & 88 & 140 & 52 & 27.4 & 20.4 & 7.0 \\
\hline 18 & & 29.8 & 7 & 87 & 129 & 43 & 31.2 & 25.0 & 6.2 \\
\hline 21 & & 34.3 & 8 & 85 & 119 & 36 & 27.7 & 22.6 & 5.2 \\
\hline Significance & & $\mathrm{L}^{* * *} \mathrm{Q} \mathrm{Q}^{* * *}$ & NS & $\mathrm{L}^{* * *} \mathrm{Q} *$ & $\mathrm{~L}^{* * *} \mathrm{Q} \mathrm{Q}^{* * *}$ & $\mathrm{~L}^{* * *} \mathrm{Q} \mathrm{Q}^{* * *}$ & NS & $\mathrm{L}^{*} \mathrm{Q}^{\mathrm{NS}}$ & $\mathrm{L}^{\mathrm{NS}} \mathrm{Q}^{* * *}$ \\
\hline 13 & 31 Oct. & 25.1 & 8 & 100 & 176 & 76 & 26.0 & 20.2 & 5.8 \\
\hline 17 & & 24.0 & 9 & 89 & 142 & 53 & 28.4 & 20.7 & 7.7 \\
\hline 18 & & 27.2 & 8 & 82 & 126 & 44 & 28.5 & 22.3 & 6.2 \\
\hline 21 & & 32.9 & 8 & 79 & 117 & 38 & 26.4 & 20.9 & 5.5 \\
\hline Significance & & $\mathrm{L}^{* * *} \mathrm{Q}^{* * *}$ & NS & $\mathrm{L}^{* * *} \mathrm{Q}^{\mathrm{NS}}$ & $\mathrm{L}^{* * *} \mathrm{Q} * * *$ & $\mathrm{~L}^{* * *} \mathrm{Q}^{* * *}$ & $\mathrm{~L}^{\mathrm{NS}} \mathrm{Q}^{*}$ & NS & $\mathrm{L}^{*} \mathrm{Q} * * *$ \\
\hline \multicolumn{10}{|c|}{ Yellow Star } \\
\hline 13 & 17 Oct. & 14.2 & 7 & 70 & 168 & 98 & 24.7 & 16.6 & 8.1 \\
\hline 17 & & 15.1 & 8 & 64 & 111 & 47 & 21.2 & 14.7 & 6.5 \\
\hline 18 & & 18.0 & 8 & 62 & 101 & 39 & 22.3 & 16.1 & 6.2 \\
\hline 21 & & 22.1 & 8 & 62 & 85 & 23 & 23.9 & 18.9 & 5.0 \\
\hline Significance & & $\mathrm{L}^{* * *} \mathrm{Q} * * \mathrm{y}$ & $\mathrm{L}^{*} \mathrm{Q} *$ & $\mathrm{~L}^{* * *} \mathrm{Q} * * *$ & $\mathrm{~L}^{* * *} \mathrm{Q} \mathrm{Q}^{* * *}$ & $\mathrm{~L}^{* * *} \mathrm{Q} \mathrm{Q}^{* * *}$ & $\mathrm{~L}^{\mathrm{NS}} \mathrm{Q}^{* *}$ & $\mathrm{~L}^{* *} \mathrm{Q}^{* *}$ & $\mathrm{~L}^{* * *} \mathrm{Q}^{\mathrm{NS}}$ \\
\hline 13 & 31 Oct. & 14.6 & 6 & 59 & 166 & 107 & 25.5 & 16.7 & 8.8 \\
\hline 17 & & 15.0 & 7 & 58 & 116 & 59 & 19.9 & 13.7 & 6.1 \\
\hline 18 & & 18.0 & 7 & 55 & 102 & 46 & 21.3 & 16.0 & 5.4 \\
\hline 21 & & 22.4 & 7 & 55 & 87 & 32 & 22.3 & 16.5 & 5.8 \\
\hline Significance & & $\mathrm{L}^{* * *} \mathrm{Q}^{* * *}$ & $\mathrm{~L}^{*} \mathrm{Q}^{\mathrm{NS}}$ & $\mathrm{L}^{* * *} \mathrm{Q}^{\mathrm{NS}}$ & $\mathrm{L}^{* * *} \mathrm{Q} \mathrm{Q}^{* * *}$ & $\mathrm{~L} * * * \mathrm{Q}^{* * *}$ & $\mathrm{~L}^{\mathrm{NS}} \mathrm{Q}^{* * *}$ & $\mathrm{~L}^{\mathrm{NS}} \mathrm{Q}^{*}$ & $\mathrm{~L}^{* * *} \mathrm{Q} \mathrm{Q}^{* * *}$ \\
\hline
\end{tabular}

Leaf length, number of leaves, plant height, scape length, and inflorescence length data were collected when first one or two florets flowered.

${ }^{y}$ Set 1 and 2 were planted on 17 Oct. and 31 Oct. 2012, respectively.

${ }^{\mathrm{z}}$ Significance of linear (L) or quadratic (Q) regression: Ns, ${ }^{*}, * *, * * *$ Nonsignificant or significant at $P \leq 0.05,0.01$, or 0.001 , respectively. 
significantly delay crop development and higher temperatures the opposite, the effects on production cost need to be calculated on an individual basis. All factors being equal higher forcing temperatures will reduce plant quality. Preplant storage at $9{ }^{\circ} \mathrm{C}$ for 3 to 4 weeks will reduce the time required to flower in the greenhouse, but depending on the cultivar, may or may not lead to earlier flowering, as compared with bulbs planted and placed immediately in the greenhouse without storage. Longer preplant cooling also increases plant height, probably increasing the need for plant growth regulators. As Ornithogalum cultivars continue to be introduced to the market, there will be an ongoing need for research on cultivar response to storage temperature and duration, greenhouse forcing temperature, and other production factors.

\section{Literature Cited}

Chouard, P. 1960. Vernalization and its relation to dormancy. Annu. Rev. Plant Physiol. 11:191-238.

Daly, M. and K. Henry. 2009. Evaluation of selected South African geophytes as winterblooming houseplants for the Northern hemisphere. Acta Hort. 813:37-44.
De Hertogh, A. and L. Gallitano. 1997. Basic forcing requirements for Israeli-grown Ornithogalum dubium. Acta Hort. 430:227-232.

Erwin, J.E., R.D. Heins, and M.G. Karlssen. 1989. Thermomorphogenesis in Lilium longiflorum Thumb. Amer. J. Bot. 76:47-52.

Huxley, A., M. Griffiths, and M. Levy. 1992. Plant reproduction. In: The new Royal Horticulture Society dictionary of gardening. Macmillan, London, UK.

Jansen van Vuuren, P.J. 1997. Predicting the flowering date of Ornithogalum thyrsoides (Jacq.). Acta Hort. 430:167-174.

Jansen van Vuuren, P.J. and L.C. Holtzhausen. 1992. The influence of temperature on phenological dating of Ornithogalum thyrsoides Jacq. as a commercial cut flower. Acta Hort. 325:119-129.

Lee, J.L., M.I. Gomez, and W.B. Miller. 2015. Paclobutrazol and flurprimidol control stem elongation of potted star of bethlehem. HortTechnology 25:480-486.

Littlejohn, G.M. and L.M. Blomerus. 1997. Evaluation of Ornithogalum genebank accessions for some characteristics of importance for breeding cut flowers or pot plants. Genet. Resources Crop Evol. 44:227-234.

Littlejohn, G.M. and L.M. Blomerus. 2000. Some factors influencing the use of Ornithogalum as a potted plant. Acta Hort. 541:253-256.
Luria, G., A.A. Watad, Y. Cohen-Zhedek, and A. Borochov. 2002. Growth and flowering of Ornithogalum dubium. Acta Hort. 570:113-119.

Miller, W.B. 2003. Commercial flower production methodology. In: B. Thomas (ed.). Encyclopedia of Applied Plant Sciences. Elsevier Academic Press, New York, NY.

Reinten, E.Y., J.H. Coetzee, and B.-E. van Wyk. 2011. The potential of South African indigenous plants for the international cut flower trade. S. Afr. J. Bot. 77:934-946.

Roh, M.S. and D.K. Hong. 2007. Inflorescence development and flowering of Ornithogalum thyrsoides hybrid as affected by temperature manipulation during bulb storage. Sci. Hort. 113:60-69.

Roh, M.S. and Y.H. Joung. 2004. Inflorescence development in an Ornithogalum dubium hybrid as influenced by bulb temperature treatments. J. Hort. Sci. Biotechnol 79:576-581.

Roh, M.S., A.K. Lee, and J.K. Suh. 2007. Induction of bulb maturity of Ornithogalum thyrsoides. Sci. Hort. 114:138-141.

Roh, M.S. and J.K. Suh. 2008. Production of quality woody and floral crops using innovative production techniques. Acta Hort. 766:29-43.

Suh, J.-K., A.-K. Lee, and J. Lee. 2000. Flowering response of Ornithogalum as influenced by temperature and plant growth regulators treatment. Acta Hort. 541:335-341. 